\title{
Neuróze e Neuròticos
}

Disse um escrítor italiano que o século XX é o século neurótico. E, principa'lmente neste,s ultimos 10 anos, o espírito humano para amoldar-se, rezistir e vencer as mutações bruscas e incessantes do meio, na rełlização de conhecida lei biolójica, sofreu profundas transformações.

Ha um dezequilibrio acentuádo entre o meio exterior, tumultuozo, dinamico e jazbandico e o Eu psicolójico, vibratil, anciozo por vencer e adaptar-se.

Daí o dezrequilibrio e o estado neurótico da época.

O homem actual é um anciozo. Daí a angustia humana. Angustia do amôr. Angustia da morte (veja-se o numero extraordinario de suicidios). Angustia da vida. E, mesmo, angustia da felicidade e da riqueza.

o módernismo, e o é todo que evolui e não tem domesticiado o pensamento, seja na arte, na filozofia ou na literatura, nada mais é que o rəflexo desse estado anciozo do penfeito, dessa grande emotividade que bem caracteriza a constituição interior do homem actual.

A neuroze ou psicoze, sindromo traduzido por sintomas variaveis, confuzos, tumultuozos, contraditórios e caóticos, récebeu ultimamente de Delmas e M. Fleury, carinhozo e profundo estudo.

Não produzindo lezão inicial, a psicoze é bem um estado constitucional. Não é bem um Estado morbido; é antes uma predispozição.

Uma constituição psicopáticla é um conjunto de tendencias. Não é uma molestia confirmada E' a creação dum terreno específico, diz Boll e Delmas, propicio ao dezenvolvimento das neurozes.

A constituição pisicopática foi classificada por Delmas em 5 grupos ou tendencias:

1) Ciclotímica - é a tendencia inata ís excitações psiquicas e ao estado de depressão melancólica. São esses individuos que têm a vida pontilhada pôr periodos breves ou longos, de excitação, de alegria, de otimismo, para logo passarem ao periodo depressivo, de fadiga, de abatimento, de tristeza, de melancolia, em que a vida se lhes parece in- 
suportavel. Neste periodo, as recordações tristes dum passado alegre, a evocação dum amôr rompido, os fazem procurar toxicomanias diversas, na ancia de uma euforia. Entre os grandes artistas se encontram alguns ciclotímicos, como Baudelaire, Verlaine e outros.

2) Emotiva - é a psico-astenia de Janet. E' a nevroze da angustia de Hartemberg.

3) Perversa - é a tendencia nativa à moral insanity dos inglezes. E' a impulsão cronica, irrefreavel de cometer actos anti-sociais. E' a tendencia a delinquencia, a assassinio. Estes individuos sentem no fundo do seu cerebro, num fluxo de sangue, o desejo aspero, violento, o desejo invencivel do crime... Não que este desejo šja manifestado numa crize passional, acompanhada de cólera irrefletida ou motivado pəla cubiça do ouro. Absolutamente. Este desejo náce rápido, poderozo, injustificado, a propózito de nada, na rua, numa festa, diante as costas de um tranzeunte ou de uma mulher bonita... As costas atráem a faca...

Conta Mirbeau a historia de um celebre assassino que matava as lindas mulheres não para roubá-las: mas para violá-las. Seu esporte era conjugar o espasmo do prazer com o espasmo da morte. Nestes individuos, o instinto à perversidade os dominam como o instinto genézico.

E, certo, a morte é o amôr sempre andaram juntos...

4) Mitomaniaca - é a mania da mentira sob a forma de contos fantasticos ou de mentira corporal, como convulsões, anestezia, contraturas, paralizia histérica. E' a tendencia mais comumente encontrada nas 'mulheres que no homem. E', mesmo, uma das armas mais poderozas ida alma feminina...

5) Paranoica - é o egocentrismo, orgulho desmedido, delirio das perseguições.

Achille Delmas, um dos mais profundos psiquiatras francezes, fez um paralelo entre estas 5 constituições anormais e os estados normais da alma humana, isto é, conjunto das faculdades afêtivas. Porque em cada um de nós, álêm das 3 aptidões que formam o nosso intelecto memoria, imajinação e julgamento - , somos dotados de dispozições naturais que constituem o nosso temperamento, a nossa individualidade propria. 
Vejamos as tendencias normais dła nossa constitulção afêtiva.

Nem todo homem é melancolico ou maniaco. Mas todos nós pośsuimos orijinariamente a tendencia à fadiga ou à infatigabilidade, à tristeza ou à vivacidade feliz; a torpôr ou a exuberancia. E' a ten. dencia - Actividade.

Não ha um sêr humano que não reaja aos estímulos do mundo exterior. E de um modo diverso conforme o individuo seja um imp̄ressionavel, um sensivel, um indifer ənte ou um impassivel. E' a tendencia de reactividade ou Fmotividade.

Assim temos desde D. Quixóte que vislumbrava exercitos quando via moinhos de vento, até o burocrata impassivelmente fechado as sensações externas, só acordando nos momentos de ajitação política distrita'l.. Temos desde a grande sensibilidade do artista até o indiferentismo do caboclo, que a'cocorado olha o mundo.

Todo o individuo não é simulador ou histérico. Mas todos os homəns se classificam entre os leais, pôlidos, amaveis, bajuladores, hipócritas e simuladores.

E' a tendencia denominada - Sociabilidade.

Nem todo o homem é perverso. E essa escala que val entre os qu? desejam o bem e o mal, daria a tendencia - Bondade.

Nós todos lutamos para vivêr. Ha os ávidos e os gananciozos. Ha os modestos e os dezinteressados. Ha o egoista e o filantrópico. E' a tendencia - Avidez.

Todos nós a temos. São felizes os que a possuem moderadamente. Sofrerão na vida os que a possuem em gráu infimo porque terão que lutar com armas deziguais. Os de avidez exagerada são nocivoś á sociedade.

Todo o homem possui no seu complexo afêtivo estas 5 dispozições ou tendencias. Da predominancia de umas ou da insuficiencia de outras, temos as diversas escalas dos caracteres humanos. Certo, não ha nenhum individuo que possua um perfeito equilibrio entre esses componentes da nossa constituição afêtiva. Um homem de grande actividade e sociabilidade, poderí sêr um grande perverso. Um artista de grande emotividade poderá sêr anti-social. Vemos, assim, que todos nós que vivemos nesta época nevrótica, somos mais ou menos dezequili. brados...

Cada uma destas tendencias, normais, correspondem, segundo Delmas, à uma constituição nəurótica. O leitôr poderá na prática ensaiar a veracidiade desta classificação. 
No meio político e social de S. Paulo, com as suas figuras e figurões, o curiozo destas coisas encontrará um vasto campo de observação e de análize.

o homəm possui uma intelijencia e uma alma, já disse o velho conselheiro Acacio.

Memoria, imajinação e julgamento, eis a intelijencia.

As cinco dispozições afêtivas que se classificou acima, eis a alma.

Na maioria dos homens ha um cərto equilibrio em todo este complexo, em tódo este trama subtilissimo. Só entramos na patoiojia mental quando as partes deste complicado sistema, quando os componentes do intelecto - e da alma se manifestam monstruozamente hipertrofiados ou lamentavelmente atrofiados.

Os componentes afêtivos e intelectuais acima aludidos, constituem toda a nossa vida mental. Estes oito componentes na sua formidavel complexidade, na sua malha delicadíssima, formam matizes infinitamente diversos: são os caracteres humanos.

Para cada organização humana, corresponde uma figura nova, uma constituição espəcial. Em cada sêr humano ha uma capacidıde especial, individual, para guardar pela memoria; de combinar, idealizar e abstrair-se pela imajinação; de comparar, verificar, raciocinar pelo julgamento. Da mesma forma tod.o homem possui, em gráu diverso, as tendencias acima mencionadas: Actividade, Emotividade, Bondade, Vera cidade ou Sociabilida a Avidez. São estas tendencias constitucionais que formam, plasmam, edificam a personalidade humana. Uma criança desde as suas primeiras atitudes, primeiros actos, primeiras palavras, refléte estas tendencias, seja em proporção equilibrada, em excesso ou insuficientemente. o conjunto dessas tendencias forma o eu fundamentel.

- Nós somos isso. E nada mais que isiso.

A influencia do meio onde o destino nos lança; os amigos; os mestres e os seus ensinamentos; os conselhos que recebemos; a moral que nos ensinam; as obras que lemos; os obstáculos que nos retêm; as lutas que sustentamos; nossos amôres; nossas dôres, diz Maúricio de Fleury, apenas cinzelam, aperfəiçoam, peneiram, subtilizam; não modificam, porêm, a essencia de nós mesmo. 
A mais perfeita educação não modifica a natureza intima, consti_ tucional do homem.

Apenas aje sobre a superficie, que polui, tinje e enverniza. Não transforma a essencia, o substráto.

Tartufo será sempre Tartufo. Damazo será sempre o Damazo.

Daí o canto popular:

Quem quer se fazer não póde, Quem é bom já nácé feito...

PAUlo De GODOY.

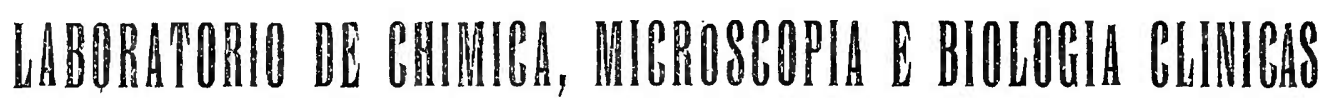

ANALYSES EM GERAL - VACCINOTHERAPIA

Dr. Aristides G. Guimarães = Dr. Oscar M. de Barros

Ph.co Mendonça Cortez

RUA DIREITA, $35-1.0$

Telephone: Central, $\mathbf{5 0 3 3}$

Caixa Postal, 1600

SÃO PAULO 